EXTENDED REPORT

\title{
Histological evidence that infliximab treatment leads to downregulation of inflammation and tissue remodelling of the synovial membrane in spondyloarthropathy
}

\author{
E Kruithof, D Baeten, F Van den Bosch, H Mielants, E M Veys, F De Keyser
}

Ann Rheum Dis 2005;64:529-536. doi: 10.1136/ard.2003.018549

See end of article for authors' affiliations

....................

Correspondence to: Dr E Kruithof, Department of Rheumatology, OK12IB, Ghent University Hospital, De Pintelaan 185, 9000 Gent, Belgium;

elli.kruithof@úGent.be

Accepted 12 August 2004 Published Online first 23 September 2004

\begin{abstract}
Objective: To confirm and extend the immunopathological evidence of effects of infliximab on the synovium in active spondyloarthropathy.

Methods: Synovial biopsies obtained in patients with spondyloarthropathy at baseline and week 12 were stained and scored by two independent observers. Two study populations were evaluated: I, a cohort of 10 patients treated with $5 \mathrm{mg} / \mathrm{kg}$ infliximab at week 0,2 , and 6, plus three placebo treated patients; and II, a pooled cohort of 20 patients fulfilling identical inclusion and exclusion criteria and treated with the same loading dose regimen.

Results: In study population I, treatment with infliximab induced reduction in synovial lining layer thickness $(p=0.015)$, endothelial activation (E-selectin, $p=0.034)$, and inflammatory cell infiltration with neutrophils $(p=0.041)$, macrophages $(p=0.034)$, and $T$ cells $(p=0.026)$, but not with $B$ cells and plasma cells; no such trends were observed in the placebo treated patients. Besides confirming the highly significant downregulation of inflammation, analysis of cohort II showed structural changes such as normalisation of lining layer thickness $(p=0.030)$, reduction in the number of blood vessels $(p=0.039)$, and downregulation of follicular organisation $(p=0.050)$. No differences in histopathological response were observed between spondyloarthropathy subtypes.

Conclusions: Profound immunomodulatory changes in the synovium parallel the clinical benefit in patients with spondyloarthropathy treated with infliximab, independently of the subtype. The study provides histological evidence that TNF $\alpha$ blockade not only downregulates inflammation but also leads to tissue remodelling.
\end{abstract}

$\mathrm{T}$ he use of biological treatments that block tumour necrosis factor $\alpha(\mathrm{TNF} \alpha)$ has opened new perspectives for the treatment of patients with spondyloarthropathy. ${ }^{1-4}$ While it is now well established that specific intervention in the immune cascade by infliximab results in remarkable clinical benefit in spondyloarthropathy, preliminary data suggest that it mightalso have a tissue remodelling effect in this condition. ${ }^{5-8}$

To gain more insight in the immunological and biological implications of this treatment, it is mandatory to have adequate surrogate markers exploring clinical efficacy and paraclinical effects. In rheumatoid arthritis, the use of serial synovial biopsies as a tool in assessing immunopathological alterations induced by targeted treatments has been well validated. ${ }^{9-12}$ In contrast, in spondyloarthropathy, this methodology of sequential synovial tissue sampling has so far scarcely been used..$^{13}{ }^{14}$ In a previous study, we explored the impact of infliximab on peripheral synovitis at the histopathological level by serial synovial biopsies in eight patients with spondyloarthropathy. ${ }^{14}$ The most striking immunohistopathological changes included a reduction in lining layer thickness and downregulation of hypervascularity and endothelial activation, resulting in a reduction in the inflammatory cell infiltrate with a differential effect on $\mathrm{T}$ and B cells.

Our aim in the present study was to evaluate the immunopathological effects of infliximab on the synovial membrane in patients with active spondyloarthropathy, employing sequential synovial tissue sampling. First, using an extended panel of immunohistochemical markers, we described the synovial membrane before and after infliximab treatment in an independent cohort of patients, and compared these data with the earlier observations as well as with a small placebo cohort. Second, as the assessment of relatively small cohorts of patients is likely to underestimate less prominent immunopathological changes and secondary tissue remodelling, histopathological data on 20 patients fulfilling identical inclusion and exclusion criteria and all receiving the same loading dose regimen of infliximab were pooled and reanalysed. In this larger cohort we examined whether spondyloarthropathy subtypes show a differential synovial response to infliximab.

\section{METHODS}

\section{Patients}

Group I: 10 infliximab treated and three placebo treated patients

Forty patients with spondyloarthropathy according to the European Spondyloarthropathy Study Group criteria ${ }^{15}$ were randomised to receive a loading dose regimen (at week 0,2 , and 6) of $5 \mathrm{mg} / \mathrm{kg}$ infliximab $(\mathrm{n}=20)$ or placebo $(\mathrm{n}=20) .{ }^{1}$ The initial 12 week placebo controlled study period was followed by an open extension phase, in which the placebo treated group switched to active treatment. The patients who were included had active disease, defined by the presence of inflammatory axial pain or peripheral synovitis, were not treated with disease modifying antirheumatic drugs or steroids, and had stable doses of non-steroidal anti-inflammatory drugs. 
Table 1 Demographic data on study populations I and II $(n=20)$

\begin{tabular}{|c|c|c|c|}
\hline \multirow[b]{2}{*}{ Variable } & \multicolumn{2}{|l|}{ Study population I } & \multirow[b]{2}{*}{$\begin{array}{l}\text { Study population I } \\
(\mathrm{n}=20)\end{array}$} \\
\hline & $\begin{array}{l}\text { Infliximab treated } \\
(\mathrm{n}=10)\end{array}$ & $\begin{array}{l}\text { Placebo treated } \\
(n=3)\end{array}$ & \\
\hline SpA subtype (AS/PsA/uSpA) & $5 / 4 / 1$ & $1 / 1 / 1$ & $10 / 8 / 2$ \\
\hline Sex (male/female) & $8 / 2$ & $3 / 0$ & $16 / 4$ \\
\hline Age (years) (median (range)) & $53(30$ to 66$)$ & 54 (44 to 66$)$ & 49 (38 to 66$)$ \\
\hline Disease duration (median (range)) & 14 (1 to 42$)$ & $39(10$ to 40$)$ & 18.5 (1 to 43$)$ \\
\hline HLA B27 (+/-/unknown) & $8 / 2 / 0$ & $2 / 1 / 0$ & $13 / 5 / 2$ \\
\hline \multicolumn{4}{|c|}{$\begin{array}{l}\text { Values are } n \text { or median (range). } \\
\text { Spondyloarthropathy subtype: AS, ankylosing spondylitis; PsA, psoriatic arthritis; USpA, undifferentiated } \\
\text { spondyloarthropathy. } \\
\text { HLA, human leucocyte antigen; SpA, spondyloarthropathy. }\end{array}$} \\
\hline
\end{tabular}

All patients gave their informed consent, as approved by the local ethics committee of the Ghent University Hospital.

For the present study, sequential needle arthroscopy was undertaken on patients selected from the main study on the basis of the presence of knee synovitis in 10 infliximab treated patients (five with ankylosing spondylitis, four with psoriatic arthritis, and one with undifferentiated spondyloarthropathy) and in three placebo treated patients (one with ankylosing spondylitis, one with psoriatic arthritis, and one with undifferentiated spondyloarthropathy). Demographic data are summarised in table 1. Data on global clinical evaluation as well as on the evaluation of peripheral arthritis in the patients at baseline and week 12 are shown in table 2 .

\section{Group II: 20 infliximab treated patients}

As the inclusion criteria, treatment and study protocols, and histological analyses were identical in the eight patients of the open pilot study, ${ }^{16}$ the 10 patients of the double blind placebo controlled study (study population I), and an additional two patients included in a compassionate use programme, we reanalysed the histopathological data of this cohort of 20 spondyloarthropathy patients ( 10 with ankylosing spondylitis, eight with psoriatic arthritis, and two with undifferentiated spondyloarthropathy) treated for 12 weeks with infliximab (5 mg/kg at week 0, 2, and 6). Demographic data for study population II are summarised in table 1

\section{Synovial histopathology}

Synovial biopsies were obtained at baseline and week 12 by needle arthroscopy of the knee, as described previously. ${ }^{17}$ Sixteen synovial biopsies were obtained in each patient. Joint lavage was restricted to a minimum $(<150 \mathrm{ml})$ and no intraarticular steroids were injected. Synovial biopsies were fixed, stained, and scored, as extensively described. ${ }^{14} 1819$ Briefly, in each patient eight paraffin embedded biopsies were stained with haematoxylin and eosin for histological analysis, including mean synovial lining layer thickness, vascularity of the sublining layer, infiltration of the sublining layer, and presence of lymphoid aggregates, plasma cells, and polymorphonuclear cells. The remaining eight biopsies were snap frozen and used for immunohistochemistry with the following monoclonal antibodies: anti-CDI46 (endothelial cells, clone PlH12; Chemicon, Temecula, California, USA), antivon Willebrand factor (anti-vWF) (endothelial cells, clone F8/ 86; Dako, Glostrup, Denmark), anti- $\alpha \mathrm{V} \beta 3$ (integrin expressed on endothelial cells, fibroblasts, osteoclasts..., clone 23C6; Pharmingen, San Diego, California, USA), anti-CD3 (T cells, clone UCHT1; Dako), anti-CD4 (T helper cells, clone MT310; Dako), anti-CD8 (T cytotoxic cells, clone DK25; Dako), antiCD19 (B cells, clone HD37; Dako), anti-CD20 (B cells, clone L26; Dako), anti-CD38 (plasma cells, clone AT13/5; Dako), anti-CD138 (plasma cells, clone CBL455; Chemicon), antiCD68 (pan-macrophage marker, clone PG-Ml; Dako), antiCDl63 (mature macrophage marker, clone Ber-MAC3; Dako), anti-CD83 (dendritic cells, clone HBl5A; Immunotech SA, Marseille, France), anti-CDla (interdigitating dendritic cells, clone NAl/34; Dako), anti-E-selectin (CD62E, endothelial leucocyte adhesion molecule 1 mainly expressed on activated endothelial cells, clone 1.2B6; Dako), antiICAM-1 (CD54, intercellular adhesion molecule 1 , clone 6.5B5; Dako), and anti-VCAM-1 (CD106, vascular cell adhesion molecule 1, clone 1.4C3; Dako). Parallel sections were incubated with irrelevant isotype and concentration matched monoclonal antibody as negative control.

Stained sections were coded and analysed by two independent observers, who were blinded for patient data, time of biopsy sampling (baseline or week 12), treatment schedule (infliximab or placebo), and patient code (sections

Table 2 Clinical evaluation of the effect of infliximab on spondyloarthropathy at baseline and week 12 in study populations I and II

\begin{tabular}{|c|c|c|c|c|c|c|}
\hline \multirow[b]{2}{*}{ Variable } & \multicolumn{3}{|c|}{ Study population I $(n=10)$} & \multicolumn{3}{|c|}{ Study population II $(n=20)$} \\
\hline & Baseline & Week 12 & p Value* & Baseline & Week 12 & p Value* \\
\hline $\begin{array}{l}\text { Patient pain (VAS) } \\
\text { Patient global (VAS) } \\
\text { Physician global (VAS) } \\
\text { ESR (mm/h) } \\
\text { C reactive protein (mg/dl) } \\
\text { Patient pain peripheral joints (VAS) } \\
\text { Duration of morning stiffness (min) } \\
\text { Tender joint count ( } \mathrm{n} \text { ) } \\
\text { Swollen joint count (n) }\end{array}$ & $\begin{array}{l}57(14 \text { to } 97) \\
64(17 \text { to } 98) \\
71(59 \text { to } 89) \\
23.5(11 \text { to } 101) \\
2.3(0.96 \text { to } 7.42) \\
55.5(20 \text { to } 90) \\
235(0 \text { to } 300) \\
10(3 \text { to } 20) \\
5.5(2 \text { to } 24)\end{array}$ & $\begin{array}{l}20(1 \text { to } 39) \\
12.5(0 \text { to } 47) \\
17(8 \text { to } 31) \\
6(1 \text { to } 34) \\
0.26(0 \text { to } 7.93) \\
18(4 \text { to } 40) \\
15(0 \text { to } 90) \\
0.5(0 \text { to } 6) \\
0.5(0 \text { to } 3)\end{array}$ & $\begin{array}{l}0.005 \\
0.005 \\
0.005 \\
0.007 \\
0.047 \\
0.007 \\
0.008 \\
0.007 \\
0.008\end{array}$ & $\begin{array}{l}69(14 \text { to } 100) \\
69(17 \text { to } 100) \\
64(35 \text { to } 89) \\
28(11 \text { to } 101) \\
3.4(1.0 \text { to } 29.0) \\
64(20 \text { to } 99) \\
133(0 \text { to } 300) \\
10(1 \text { to } 20) \\
7(0 \text { to } 24)\end{array}$ & $\begin{array}{l}16(1 \text { to } 86) \\
15(0 \text { to } 73) \\
15(8 \text { to } 75) \\
7(1 \text { to } 59) \\
0.3(0 \text { to } 7.9) \\
18(0 \text { to } 84) \\
10(1 \text { to } 90) \\
0(0 \text { to } 6) \\
1(0 \text { to } 7)\end{array}$ & $\begin{array}{l}<0.001 \\
<0.001 \\
<0.001 \\
<0.001 \\
0.001 \\
<0.001 \\
<0.001 \\
<0.001 \\
<0.001\end{array}$ \\
\hline \multicolumn{7}{|c|}{$\begin{array}{l}\text { Results are expressed as median (range). } \\
\text { Global and peripheral joint assessments on a } 100 \mathrm{~mm} \text { visual analogue scale. } \\
\text { *p Values calculated using the paired Wilcoxon signed rank test. } \\
\text { ESR, erythrocyte sedimentation rate; VAS, visual analogue scale. }\end{array}$} \\
\hline
\end{tabular}


A
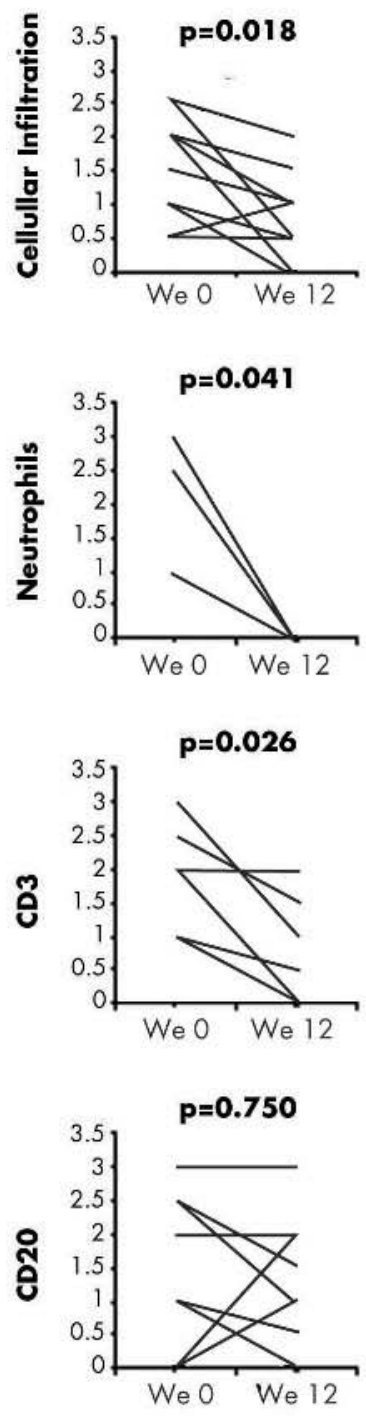

$p=0.516$

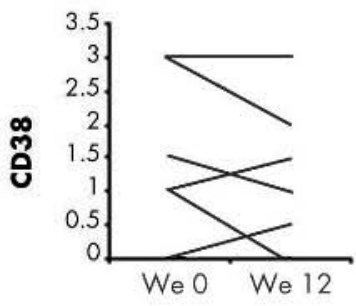

$p=0.034$

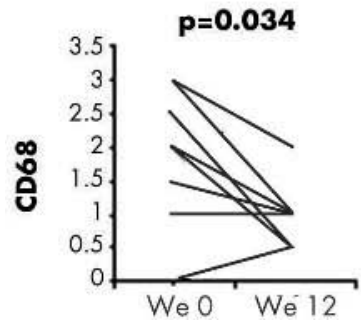

B
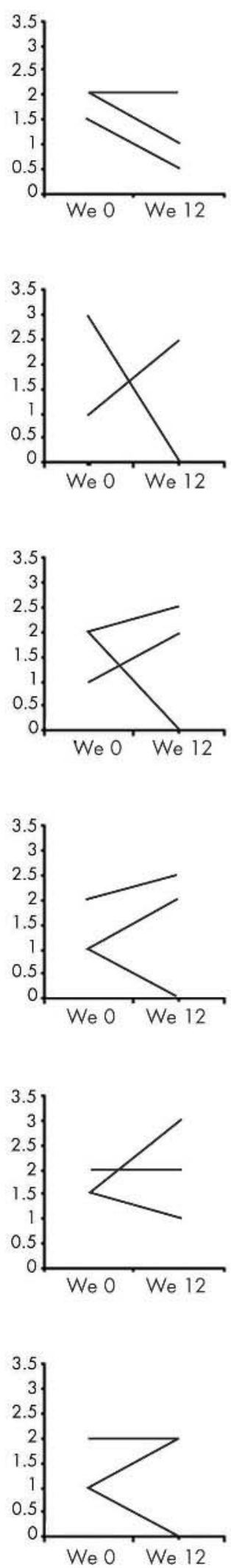

C

D
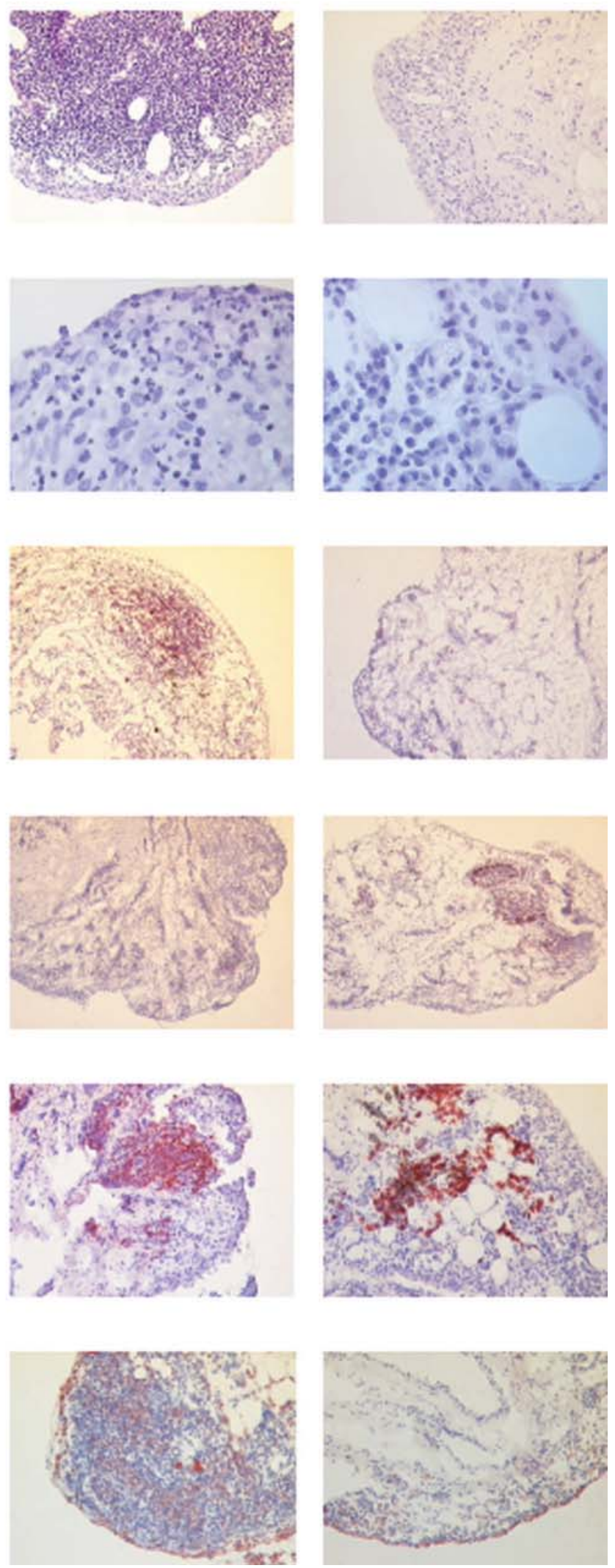

Figure 1 Immunomodulatory effect of infliximab $(A=$ study population $I, n=10)$ or placebo $(B=$ study population $I, n=3)$ on synovial histology in patients with active spondyloarthropathy. Synovial biopsies obtained at week 0 and week 12 were scored on a semiquantitative scale (0-3) by two independent observers ( $p$ value calculated using the paired Wilcoxon signed ranks test for study population I). Representative sections of the evaluation at baseline (C) and at week 12 (D) in infliximab treated patients (study population I) are shown, and the corresponding semiquantitative score for each picture is indicated. The variables evaluated included: the degree of inflammatory cell infiltration (score 2.5 at baseline, score 0.5 at week 12); the number of neutrophils (score 3 at baseline, score 0 at week 12); the number of CD3+ T cells (score 2 at baseline, score 0 at week 12); the number of CD20+ B cells (score 0 at baseline, score 2 at week 12); the number of CD38+ plasma cells (score 3 at baseline, score 3 at week 12); and the number of CD68+ macrophages (score 2 at baseline, score 1 at week 12). 
A
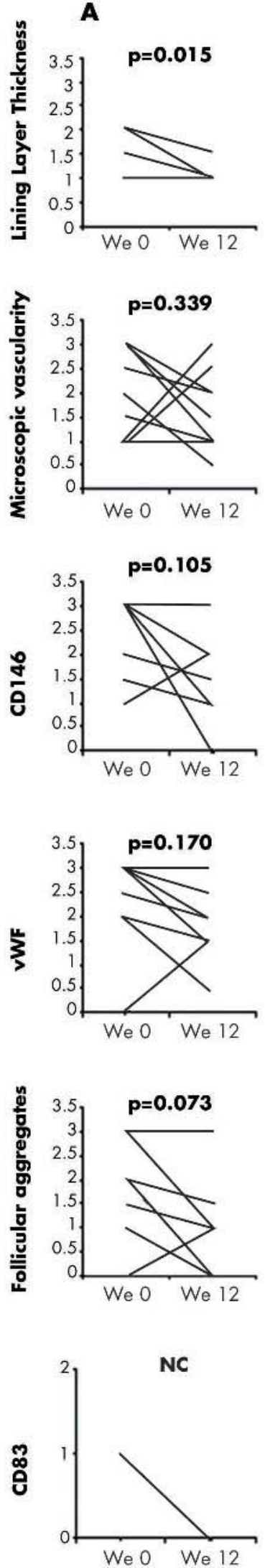

B
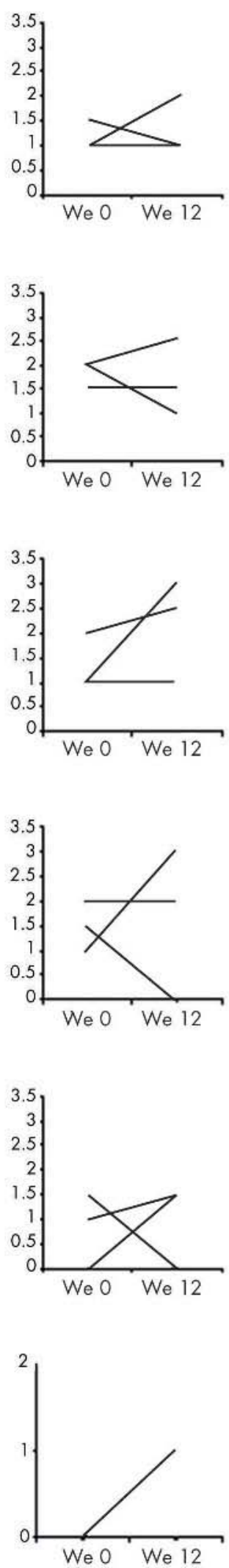

C
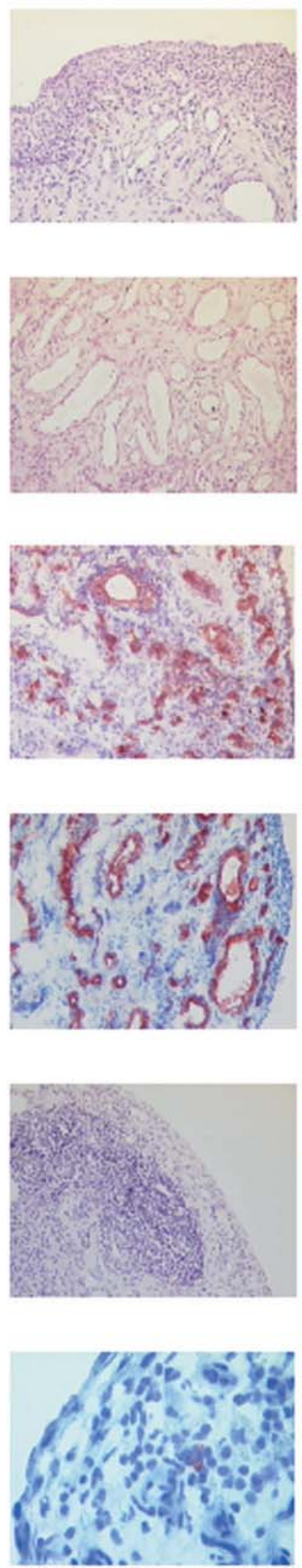
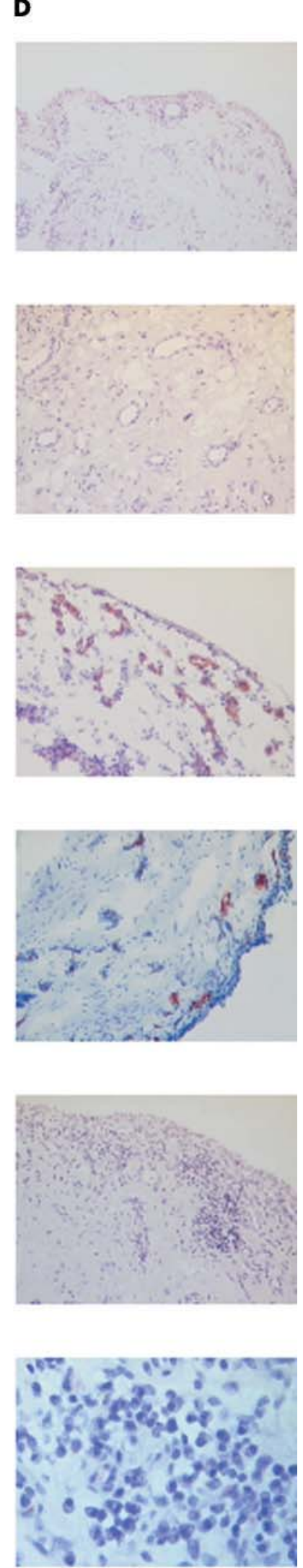

Figure 2 Tissue remodelling effect of infliximab $(A=$ study population $I, n=10)$ or placebo $(B=$ study population $I, n=3)$ on synovial histology in patients with active spondyloarthropathy. Synovial biopsies obtained at week 0 and week 12 were scored on a semiquantitative scale (0-3) by two independent observers ( $p$ value calculated using the paired Wilcoxon signed ranks test for study population I). Representative sections of the evaluation in infliximab treated patients (study population I) at baseline (C) and at week 12 (D) are shown, and the corresponding semiquantitative score for each picture is indicated. The variables evaluated included: the synovial lining layer thickness (score 2 at baseline, score 1 at week 12); the degree of vascularity (score 3 at baseline, score 1 at week 12); the number of CD 146+ endothelial cells (score 3 at baseline, score 1 at week 12); endothelial expression of von Willebrand factor (score 3 at baseline, score 1 at week 12); the degree of follicular formation (score 2 at baseline, score 1,5 at week 12); and the presence of CD83+ dendritic cells (present at baseline, absent at week 12). NC, not calculable. 
Table 3 Histological and immunohistochemical evaluation in spondyloarthropathy at baseline and week 12 in infliximab treated patients of study population I ( $n=10)$

\begin{tabular}{|c|c|c|c|}
\hline & \multicolumn{2}{|c|}{ Study population I ( $n=10$ infliximab) } & \multirow[b]{2}{*}{$\mathrm{p}$ Value } \\
\hline & Baseline & Week 12 & \\
\hline \multicolumn{4}{|l|}{ Lining layer } \\
\hline Synovial lining layer thickness & $1.5(1$ to 2$)$ & $1(1$ to 1.5$)$ & 0.015 \\
\hline$\alpha \vee \beta 3$ lining & $0(0$ to 3$)$ & $1(0$ to 2.5$)$ & 0.516 \\
\hline VCAM-1 lining & $3(1.5$ to 3$)$ & 1.5 (1 to 3 ) & 0.034 \\
\hline ICAM-1 lining & $3(1.5$ to 3$)$ & $2.5(1.5$ to 3$)$ & 0.238 \\
\hline E-selectin lining & $0(0$ to 1.5$)$ & $0(0$ to 0.5$)$ & 0.180 \\
\hline CD163 lining & $2(0$ to 2.5$)$ & $1.5(0$ to 3$)$ & 0.864 \\
\hline \multicolumn{4}{|l|}{ Blood vessels } \\
\hline Vascularity & 1.75 (1 to 3 ) & $1.25(1$ to 2.5$)$ & 0.339 \\
\hline von Willebrand factor & $3(0$ to 3$)$ & $1.5(1$ to 3$)$ & 0.170 \\
\hline CD146 & $3(1$ to 3$)$ & $1.5(0$ to 3$)$ & 0.105 \\
\hline$\alpha \vee \beta 3$ endothelial & $1(0$ to 2.5$)$ & $0(0$ to 1.5$)$ & 0.058 \\
\hline VCAM-1 endothelial & $0(0$ to 1.5$)$ & $0(0$ to 1.5$)$ & 0.180 \\
\hline ICAM-1 endothelial & $3(0$ to 3$)$ & $2.5(1$ to 3$)$ & 1.000 \\
\hline E-selectin endothelial & $1.5(0$ to 3$)$ & $1(0$ to 2.5$)$ & 0.230 \\
\hline \multicolumn{4}{|l|}{ Sublining layer } \\
\hline VCAM-1 sublining & $1(0$ to 3$)$ & $0(0$ to 2.5$)$ & 0.173 \\
\hline ICAM-1 sublining & $3(0$ to 3$)$ & $1.25(0.5$ to 3$)$ & 0.141 \\
\hline E-selectin sublining & $2(0.5$ to 3$)$ & $1(0$ to 2$)$ & 0.034 \\
\hline Degree of inflammatory cell infiltration & $1.75(0.5$ to 2.5$)$ & 0.75 (0 to 2 ) & 0.018 \\
\hline Number of neutrophils & $0.5(0$ to 3$)$ & $0(0$ to 0$)$ & 0.041 \\
\hline Number of lymphoid aggregates & $1.75(0$ to 3$)$ & $0.5(0$ to 3$)$ & 0.073 \\
\hline CD3 & $2(0$ to 3$)$ & 0.5 (0 to 2$)$ & 0.026 \\
\hline CD4 & $1.5(0$ to 3$)$ & 0.5 (0 to 2$)$ & 0.076 \\
\hline CD8 & $2(0$ to 2.5$)$ & $1(0$ to 1$)$ & 0.061 \\
\hline CD19 & $1(0$ to 3$)$ & $0(0$ to 1$)$ & 0.059 \\
\hline CD20 & $1.5(0$ to 3$)$ & $1(0$ to 3$)$ & 0.750 \\
\hline Number of plasma cells & $0.5(0$ to 3$)$ & $0(0$ to 3$)$ & 0.258 \\
\hline CD38 & $1.5(0$ to 3$)$ & $1.5(0$ to 3$)$ & 0.516 \\
\hline CD138 & $1(0$ to 3$)$ & $1(0$ to 3$)$ & 0.680 \\
\hline CD68 & $2(0$ to 3$)$ & $1(0.5$ to 2$)$ & 0.034 \\
\hline CD163 & $1.25(0$ to 3$)$ & 0.5 (0 to 2.5 ) & 0.469 \\
\hline CD83 (+/-) & $4 / 9$ & $0 / 9$ & NC \\
\hline CDla $(+/-)$ & $6 / 9$ & $2 / 9$ & 0.125 \\
\hline \multicolumn{4}{|c|}{$\begin{array}{l}\text { Semiquantitative histological and immunohistochemical scores are given as median (range). The } \\
\text { immunohistochemical markers CD83 and CDla (sublining layer) were scored as present (+) or absent }(-) \text {. The } p \\
\text { value was calculated for study population I using the paired Wilcoxon signed rank test for the semiquantitative } \\
\text { scores and the McNemar test for the dichotomous scores. } \\
\text { NC, not calculable. }\end{array}$} \\
\hline
\end{tabular}

were not scored by pair). The analysis included all areas of the biopsies and a global score was given for each variable, using a semiquantitative four point scale: 0 represented the lowest and 3 the highest level of expression. In case of discordant scores between the two observers, the mean of the two scores was used. As the number of positive cells per synovial section for CD83 and CDla was too small to be scored semiquantitatively, this variable was scored as present or absent.

\section{Statistical analysis}

Scores obtained at week 12 were compared with baseline scores using the paired Wilcoxon signed rank test. Probability (p) values less than 0.05 were considered statistically significant. In order to minimise the type II error and thus avoid a reduction in sensitivity, the Bonferroni correction was not applied.

\section{RESULTS}

\section{Clinical evaluation}

Evaluation of the clinical efficacy of anti-TNF $\alpha$ treatment in spondyloarthropathy in the 12 week, placebo controlled, double blind trial has been described extensively before, results demonstrating a highly significant improvement in global disease activity, inflammatory indices, and peripheral synovitis. ${ }^{1}$ As shown in table 2, the infliximab treated patients of cohort I selected for histological evaluation of peripheral synovitis behaved in a similar way to the global group with regard to the baseline values and response to treatment, with a clear improvement in global clinical indices as well as peripheral arthritis by week 12 compared with baseline. At baseline, clinical synovitis of the biopsied knee joint was present in all patients, whereas by week 12 only three of the 10 patients still had a swollen knee. The three placebo treated patients selected for histological evaluation behaved clinically in a similar way to the placebo cohort reported in the double blind, placebo controlled trial, ${ }^{1}$ with no clinical improvement at week 12 compared with baseline.

All 20 patients from study population II showed significant improvement on all clinical assessments of disease activity by week 12 compared with baseline (table 2).

\section{Histological and immunohistochemical evaluation of study population I}

The histological evaluation of study population I is summarised in table 3 and illustrated in figs 1 and 2 .

Synovial lining layer thickness was increased (three to five cell layers) at baseline in seven of the 10 patients and was normal (one to two cell layers) in nine patients at week 12 $(p=0.015)$. Expression of $\alpha \mathrm{V} \beta 3$ in the lining layer was not altered $(\mathrm{p}=0.516)$. A significant reduction in VCAM-1 expression $(p=0.034)$ was observed at week 12 compared with baseline, whereas the expression of ICAM- $1(p=0.238)$ did not change. Although E-selectin was mainly expressed on 
Table 4 Histological and immunohistochemical evaluation of the effect of infliximab $15 \mathrm{mg} / \mathrm{kg}$ intravenously at week 0 , week 2 , and week 6 ) on the synovial membrane in study population II $(n=20)$

\begin{tabular}{|c|c|c|c|}
\hline \multirow[b]{2}{*}{ Variable } & \multicolumn{2}{|c|}{$\begin{array}{l}\text { Study population II } \\
\text { ( } n=20 \text { infliximab) }\end{array}$} & \multirow[b]{2}{*}{ p Value } \\
\hline & Baseline & Week 12 & \\
\hline \multicolumn{4}{|l|}{ Lining layer } \\
\hline Synovial lining layer thickness & 1.5 (1 to 2$)$ & 1 (1 to 1.5$)$ & 0.003 \\
\hline$\alpha \vee \beta 3$ lining & $0(0$ to 3$)$ & $0(0$ to 2.5$)$ & 0.856 \\
\hline CD163 lining & $2(0$ to 3$)$ & $1.25(0$ to 3$)$ & 0.061 \\
\hline \multicolumn{4}{|l|}{ Blood vessels } \\
\hline Vascularity & $2(1$ to 3$)$ & $1.5(0.5$ to 3$)$ & 0.039 \\
\hline$\alpha \vee \beta 3$ endothelial & $0(0$ to 2.5$)$ & $0(0$ to 1.5$)$ & 0.024 \\
\hline E-selectin endothelial & $1(0$ to 3$)$ & $0.5(0$ to 2.5$)$ & 0.083 \\
\hline ICAM-1 endothelial & $2(0$ to 3$)$ & $2(1$ to 3$)$ & 1.000 \\
\hline VCAM-1 endothelial & 0 (0 to 2.5 ) & $0(0$ to 1.5$)$ & 0.018 \\
\hline \multicolumn{4}{|l|}{ Sublining layer } \\
\hline E-selectin sublining & $1(0$ to 3$)$ & $0(0$ to 2$)$ & 0.006 \\
\hline ICAM-1 sublining & $2.5(0$ to 3$)$ & $1(0$ to 3$)$ & 0.007 \\
\hline VCAM-1 sublining & $2(0$ to 3$)$ & $1(0$ to 3$)$ & 0.047 \\
\hline \multicolumn{4}{|l|}{ Degree of inflammatory cell } \\
\hline infiltration & 1.75 (0 to 3$)$ & $1(0$ to 2.5$)$ & 0.017 \\
\hline $\begin{array}{l}\text { Number of neutrophils } \\
\text { Number of lymphoid }\end{array}$ & $0.5(0$ to 3$)$ & $0(0$ to 0.5$)$ & 0.005 \\
\hline aggregates & 0.25 (0 to 3$)$ & $0(0$ to 3$)$ & 0.050 \\
\hline CD3 & $1(0$ to 3$)$ & $1(0$ to 3$)$ & 0.073 \\
\hline CD4 & $1(0$ to 3$)$ & $0.5(0$ to 2$)$ & 0.004 \\
\hline CD8 & $1(0$ to 3$)$ & $1(0$ to 3$)$ & 0.013 \\
\hline CD20 & $1(0$ to 3$)$ & $1(0$ to 3$)$ & 0.486 \\
\hline Number of plasma cells & $0(0$ to 3$)$ & 0.25 (0 to 3$)$ & 0.749 \\
\hline CD68 & $1.5(0$ to 3$)$ & $0.5(0$ to 2$)$ & 0.002 \\
\hline CD163 sublining & $1.25(0$ to 3$)$ & 0.5 (0 to 2.5 ) & 0.050 \\
\hline
\end{tabular}

Results are expressed as median (range). The $p$ values were calculated using the paired Wilcoxon signed rank test.

endothelial cells, it was also detected in the lining layer. No significant change in E-selectin expression could be observed at week 12 compared with baseline $(p=0.180)$, although this might be because E-selectin expression in the lining at baseline was only observed in three of eight patients; by week 12 this number was reduced to one of eight. There was no alteration in CD163 expression in the lining layer $(p=0.864)$.

Vascularity tended to diminish, with a decrease in seven of the 10 patients and an increase in two $(p=0.339)$. We observed a similar tendency for CD146 $(p=0.105)$ and von Willebrand factor $(p=0.170)$, with a decrease in both CDl46+ and vWF+ blood vessels in six of eight patients and an increase in only one. Moreover, the expression of $\alpha \mathrm{V} \beta 3$ in the sublining - a marker for neovascularisationtended to decrease after treatment with infliximab $(p=0.058)$. Endothelial expression of the different adhesion molecules did not change after infliximab treatment.

In the sublining, expression of E-selectin, which probably mimicks non-endothelial cell staining caused by vessel sprouting $(p=0.034)$, was significantly reduced after treatment with infliximab. A similar trend for VCAM-1 was found $(\mathrm{p}=0.180$, with a decrease in five of eight patients and an increase in only two $)$ and for ICAM-1 ( $p=0.141$, with a decrease in five and an increase in one).

The overall degree of inflammatory cell infiltration was reduced at week 12 compared with baseline $(p=0.018)$, with a trend towards reduction in the number of lymphoid aggregates $(p=0.073)$. This was paralleled by a significant reduction in neutrophil infiltration $(p=0.041)$ : in five of 10 patients neutrophil infiltration was present at baseline, but by week 12 none of the patients showed such infiltration. The number of lymphocytes positive for CD3 was decreased at week 12 compared with baseline $(\mathrm{p}=0.026)$, with a similar trend for CD4+ $(p=0.076)$ and CD8+ $(p=0.061)$ T cell infiltration. The number of CD19+ lymphocytes tended to decrease $(p=0.059)$, whereas no such trend was observed for CD20+ B cells or CD38+ and CD138+ plasma cells. The number of CD68+ macrophages in the sublining layer was significantly reduced at week $12(\mathrm{p}=0.034)$; however, the number of CDl63+ cells was not altered $(p=0.469)$. At baseline, in four of nine patients CD83+ dendritic cells were observed, whereas by week 12 such cells could no longer be found. Similarly, CDla+ interdigitating dendritic cells were present in six of nine patients at baseline, and in only two patients by week 12 .

In contrast to the infliximab treated patients, none of the histological characteristics or immunohistochemical markers changed consistently between baseline and week 12 in the placebo cohort.

\section{Histological and immunohistochemical evaluation of study population II}

The data are summarised in table 4 .

At baseline, lining layer hyperplasia was present in 11 of 20 patients, whereas after infliximab treatment, 19 of 20 patients had a normal lining layer thickness $(p=0.030)$. The expression of $\alpha \mathrm{V} \beta 3$ in the lining layer was not modified $(\mathrm{p}=0.856)$. CDl63 expression showed a trend towards reduction, with a decrease in 10 of the 20 patients, unchanged in six, and increased in only four $(p=0.061)$.

Vascularity was significantly decreased at week 12 compared with baseline $(p=0.039)$, and this was paralleled by downregulation of the neovascularisation marker $\alpha \mathrm{V} \beta 3$ $(p=0.024)$. Evaluation of the endothelial expression of the adhesion molecules revealed a significant downregulation of VCAM- 1 at week 12 compared with baseline $(p=0.018)$, and a similar trend for E-selectin $(p=0.083$, with a decrease in nine of 18 patients and an increase in only three; in five of the six patients with no change, baseline values were already zero. Endothelial expression of ICAM-1 did not change after treatment with infliximab $(\mathrm{p}=1.000)$.

When evaluating the expression of adhesion molecules in the sublining, significant downregulation was found for VCAM-1 $(p=0.047)$, ICAM-1 $(p=0.007)$, and E-selectin $(\mathrm{p}=0.006)$.

Overall inflammatory cell infiltration $(p=0.017)$ and the presence of lymphoid aggregates $(p=0.050)$ were both reduced by week 12 . This coincided with a significant reduction in the number of neutrophils $(p=0.005)$, CD4+ $(p=0.004)$ and CD8+ $(p=0.013) \quad T$ cells, and CD68+ $(p=0.002)$ and CDl63+ $(p=0.050)$ macrophages. A similar trend was found for CD3+ T cells $(p=0.073)$. However, no change in numbers of CD20+ B cells $(p=0.468)$ or plasma cells $(p=0.749)$ was found.

\section{DISCUSSION}

In this study we analysed an independent cohort of 10 infliximab treated spondyloarthropathy patients in whom baseline synovial tissue samples had characteristics suggestive of spondyloarthropathy synovitis: moderate lining hyperplasia, strong hypervascularisation with endothelial activation, and moderate and diffuse inflammatory infiltration with macrophages, lymphocytes, and polymorphonuclear cells. ${ }^{1820}$ After 12 weeks of infliximab treatment, the previously reported effects were confirmed-that is, reduction in synovial lining layer thickness, endothelial activation, and inflammatory cell infiltration with polymorphonuclear cells, macrophages, and $\mathrm{T}$ cells but not $\mathrm{B}$ cell and plasma cells. $^{14}$ In addition, the panel of immunohistochemical markers was extended by specific markers for vascularity (vWF, CD146), B cells (CD19), plasma cells (CD38, CD138), and dendritic cells (CDla, CD83). These stainings confirmed 
that there was no significant decrease in B cells or plasma cells. While we noted a slight trend for CD19 (but not the other B cell markers) to decrease, these data essentially indicate that the effect of infliximab on the B cell lineage is less pronounced than on the $\mathrm{T}$ lymphocytes, macrophages, and neutrophils.

The additional stainings also indicate a significant decrease in vascularity, as reflected by a downregulation of vWF and CD146 expression. Furthermore, we provided new evidence for a decrease in the follicular organisation of the residual inflammatory infiltration, which was paralleled by a decrease in follicular dendritic cells, as identified by CDla and CD83. Another new indication of the present study is that these findings in infliximab treated patients contrasted with histopathological findings in three placebo treated patients, in whom there was no tendency at all towards reduction in the synovial inflammation; on the contrary, the scores varied in both directions. This indicates that the observed changes in the treated group were not biased by the needle arthroscopy, the biopsy sampling procedure, or the analysis methodology, as has previously been shown in rheumatoid arthritis. ${ }^{21}$

Besides the fact that the present study confirmed and extended our pilot observations, ${ }^{14}$ another important aspect is that both studies were conducted in exactly the same way (patient inclusion, treatment regimen, biopsy sampling, and histological analysis), so that the data can be pooled and analysed together. Indeed, a major drawback of this kind of approach is the relatively small number of observations: significant changes observed in a small cohort probably reflect genuine phenomena, as evidenced by the present confirmation study, but discrete alterations in synovial histopathology may be overlooked more readily. These include putative alterations that would be observed in only a subgroup of the spondyloarthropathy population. We therefore pooled the histopathological data on 20 spondyloarthropathy patients. The analysis of this pooled cohort generated some important new conclusions: the trend towards downregulation of the endothelial expression of $\alpha \mathrm{V} \beta 3$ and VCAM-1, expression in the sublining of ICAM-1 and VCAM-1, and the presence of lymphoid aggregates and CD4+ and CD8+ cells reached significance in study population II.

Although CD68 and CD163 are both expressed by macrophages, they do not identify the same cell populations: CD68 is a pan-macrophage marker, whereas CDI63 is expressed on activated macrophages in an advanced maturation stage. ${ }^{22} 23$ Moreover, recent evidence indicates that CDl63 not only identifies a separate macrophage subpopulation, but also confers specific functional capacities which may be important in the pathogenesis of spondyloarthropathy. ${ }^{24}$ Although we did not observe downregulation of CD163 in patient cohort I, after pooling the data a consistent trend towards a decrease in CD163 in the lining and sublining was noticed $(p=0.061$ and $p=0.050$, respectively), and this in accordance with the finding of downregulation of CD68 positive cells.

Not only could a highly significant downregulation of immune activation and inflammation be demonstrated in this larger cohort, but these changes also resulted in a trend towards normalisation of the histology of the synovial membrane. Structural changes involving normalisation of lining layer thickness and significant downregulation of the number of blood vessels were witness to this trend and confirmed that interfering with $\mathrm{TNF} \alpha$ not only modulates inflammation but can also restore the tissue architecture. Whether these changes can lead to complete normalisation should be studied by evaluating synovial biopsies sampled after a longer period of infliximab treatment. On the other hand, our recent observations of profound downmodulation of matrix metalloproteinases in spondyloarthropathic synovium by infliximab treatment could fit with the hypothesis that structural remodelling of the synovium precedes structural changes in bone and cartilage. ${ }^{25}$ This would substantiate some of the preliminary observations made in patients with psoriatic arthritis, in whom remission was paralleled by the radiological observation of remodelling of damaged finger joints. ${ }^{82}$

Beside the demonstration of tissue remodelling, this pooled cohort of 20 patients also allowed us to explore whether there are subtle differences in synovial histology between the spondyloarthropathy subtypes or in responses to treatment. The comparison of the immunohistopathological response between the subtypes ankylosing spondylitis $(n=10)$ and psoriatic arthritis $(\mathrm{n}=8)$ did not reveal any significant differences (results not shown). Though the number of patients in the subgroups was small, spondyloarthropathy subtypes as such do not appear to show a highly discriminative immunohistopathological architecture at baseline. ${ }^{27}$ Moreover, the synovial evaluation after infliximab treatment was in accordance with the observation that the clinical response between the subtypes is not significantly different either, underscoring the overall similarity of the different spondyloarthropathy subsets as far as peripheral synovitis and response to inflixmab treatment is concerned (unpublished data).

\section{Conclusions}

The similar findings in two independent infliximab treated cohorts (but not in placebo patients), and the fact that the histological analysis confirmed the clinical benefit of infliximab in spondyloarthropathy, indicate the potential of sequential synovial tissue analysis as a surrogate marker in evaluating targeted treatments in spondyloarthropathy. In addition, the observation of downmodulation of inflammation as well as structural remodelling of the synovium warrants a longer term prospective evaluation of structural repair by $\mathrm{TNF} \alpha$ blockade, by a combined histological and radiological approach. Finally, our study provided no evidence that peripheral synovitis in different spondyloarthropathy subtypes responds differentially to infliximab treatment.

\section{ACKNOWLEDGEMENTS}

We are indebted to Schering-Plough and Centocor (F Cornillie PhD) for the supply of the study drug. We wish to thank Jenny Vermeersch for her excellent technical contribution to this study, and Annemie Herssens and Ilse Hoffman for their assistance during the arthroscopy procedures.

\section{Authors' affiliations \\ E Kruithof, D Baeten, F Van den Bosch, H Mielants, E M Veys, \\ F De Keyser, Department of Rheumatology, Ghent University Hospital, Ghent, Belgium}

\section{REFERENCES}

1 Van den Bosch F, Kruithof E, Baeten D, Herssens A, De Keyser F, Mielants H, et al. Randomised double-blind comparison of chimeric monoclonal antibody to tumor necrosis factor $\alpha$ (infliximab) versus placebo in active spondyloarthropathy. Arthritis Rheum 2002;46:755-65.

2 Braun J, Brandt J, Listing J, Zink A, Alten R, Golder W, et al. Treatment of active ankylosing spondylitis with infliximab: a randomised controlled multicentre trial. Lancet 2002;359:1 187-93.

3 Mease PJ, Goffe BS, Metz J, VanderStoep A, Finck B, Burge DJ. Etanercept in the treatment of psoriatic arthritis and psoriasis: a randomised trial. Lancet 2000;356:385-90.

4 Gorman JD, Sack KE, Davis JC. Treatment of ankylosing spondylitis by inhibition of tumor necrosis factor alpha. N Engl J Med 2002;346:1349-56.

5 Knight DM, Trinh H, Le J, Siegel S, Shealy D, McDonough M, et al. Construction and initial characterization of a mouse-human chimeric anti-TNF antibody. Mol Immunol 1993;30:1443-53.

6 Braun J, Baraliakos X, Golder W, Brandt J, Rudwaleit M, Listing J, et al. Magnetic resonance imaging examinations of the spine in patients with 
ankylosing spondylitis, before and after successful therapy with infliximab. Arthritis Rheum 2003;48:1126-36.

7 Allali F, Breban M, Porcher R, Maillefert JF, Dougados M, Roux C. Increase in bone mineral density of patients with spondyloarthropathy treated with antitumour necrosis factor alpha. Ann Rheum Dis 2003;62:347-9.

8 Kruithof E, Van den Bosch F, Baeten D, De Keyser F, Mielants H, Veys EM. Structure modifying properties of TNF-alpha blockade with infliximab in psoriatic arthritis: a case report. Clin Rheumatol 2001;20:417.

9 Tak PP, Taylor PC, Breedveld FC, Smeets TJM, Daha MR, Kluin PM, et al. Decrease in cellularity and expression of adhesion molecules by anti-tumor necrosis factor alpha treatment in patients with rheumatoid arthritis. Arthritis Rheum 1996;39:1077-81.

10 Taylor PC, Peters AM, Paleolog E, Chapman PT, Elliott MJ, McCloskey R, et al. Reduction of chemokine levels and leucocyte traffic to joints by tumor necrosis factor alpha blockade in patients with rheumatoid arthritis. Arthritis Rheum 2000;43:38-47.

11 Ulfgren AK, Andersson U, Engstrom M, Klareskog L, Maini RN, Taylor PC. Systemic anti-tumor necrosis factor alpha therapy in rheumatoid arthritis down-regulates synovial tumor necrosis factor alpha synthesis. Arthritis Rheum 2000;43:2391-6.

12 Catrina Al, Lampa J, Ernestam S, af Klint E, Bratt J, Klareskog L, et al. Antitumour necrosis factor (TNF)-alpha therapy (etanercept) down-regulates serum matrix metalloproteinase (MMP)-3 and MMP-1 in rheumatoid arthritis. Rheumatology 2002;41:484-9.

13 Mclnnes IB, Illei GG, Danning CL, Yarboro CH, Crane M, Kuroiwa T, et al. IL10 improves skin disease and modulates endothelial activation and leucocyte effector function in patients with psoriatic arthritis. J Immunol $2001: 167: 4075-82$

14 Baeten D, Kruithof E, Van den Bosch F, Demetter P, Van Damme N, Cuvelier $\mathrm{C}$, et al. Immunomodulatory effects of anti-tumor necrosis factor $\alpha$ therapy on synovium in spondylarthropathy: histologic findings in eight patients from an open-label pilot study. Arthritis Rheum 2001;44:186-95.

15 Dougados M, van der Linden S, Juhlin R, Huiffeldt B, Amor B, Calin A, et al. The European Spondyloarthropathy Study Group preliminary criteria for classification of spondyloarthropathy. Arthritis Rheum 1991;34:1218-27.

16 Van den Bosch F, Kruithof E, Baeten D, De Keyser F, Mielants H, Veys EM. Effects of a loading dose regimen of 3 infusions of chimeric monoclonal antibody to tumor necrosis factor alpha (infliximab) in spondyloarthropathy: an open pilot study. Ann Rheum Dis 2000;59:428-33.
17 Baeten D, Van den Bosch F, Elewaut D, Stuer A, Veys EM, De Keyser F. Needle arthroscopy of the knee with synovial biopsy sampling: technical experience in 150 patients. Clin Rheumatol 1999; 18:434-41.

18 Baeten D, Demetter P, Cuvelier C, Van den Bosch F, Kruithof E, Van Damme N, et al. Comparative study of synovial histology in rheumatoid arthritis, spondyloarthropathy and osteoarthritis: influence of disease duration and activity. Ann Rheum Dis 2000;59:945-53.

19 Baeten D, Demetter P, Cuvelier CA, Kruithof E, Van Damme N, De Vos M, et al. Macrophages expressing the scavenger receptor CD163: a link between immune alterations of the gut and synovial inflammation in immune alterations of the gut and synovial inflamm
spondyloarthropathy. J Pathol 2002; 196:343-50.

20 Veale D, Yanni G, Rogers S, Barnes L, Bresnihan B, Fitzgerald O. Reduced synovial membrane macrophage numbers, ELAM-1 expression, and lining layer hyperplasia in psoriatic arthritis as compared with rheumatoid arthritis. Arthritis Rheum 1993;36:893-900.

21 Smeets TJ, Kraan MC, Versendaal J, Breedveld FC, Tak PP. Analysis of serial synovial biopsies in patients with rheumatoid arthritis: description of a control group without clinical improvement after treatment with interleukin 10 or placebo. J Rheumatol 1999;26:2089-93.

22 Sanchez C, Domenech N, Vazquez J, Alonso F, Ezquerra A, Dominguez J. The porcine 2A10 antigen is homologous to human CD163 and related to macrophage differentiation. J Immunol 1999;162:5230-37.

23 Van den Heuvel MM, Tensen CP, van As JH, Van den Berg TK, Fluitsma DM, Dijkstra CD, et al. Regulation of CD163 on human macrophages: cross-linking of CD163 induces signalling and activation. J Leukoc Biol 1999;66:858-66.

24 Baeten D, Moller HJ, Delanghe J, Veys EM, Moestrup SK, De Keyser F. Association of CD163+ macrophages and local production of soluble CD163 with decreased lymphocyte activation in spondylarthropathy synovitis. Arthritis Rheum 2004;50:1611-23.

25 Vandooren B, Kruithof E, Yu DTY, Rihl M, Gu J, De Rycke L, et al. Involvement of matrix metalloproteinases and their inhibitors in peripheral synovitis and down-regulation by tumor necrosis factor $\alpha$ blockade in spondylarthropathy. Arthritis Rheum 2004;50:2942-53.

26 Ory P, Sharp JT, Salonen D, Rubenstein J, Mease PJ, Kivitz AJ, et al. Etanercept (Enbre ${ }^{\circledR}$ ) inhibits radiographic progression in patients with psoriatic arthritis [abstract]. Arthritis Rheum 2002:46:S196.

27 Baeten D, Kruithof E, De Rycke L, Hoffman LEA, Vandooren B, Mielants H, et al. Differential histopathology of the synovial membrane in spondyloarthropathy subtypes and rheumatoid arthritis [abstract]. Arthritis Rheum 2002;46:S440. 